\title{
Gliridae (Rodentia) from the Villafranchian site of Węże 2 in southern Poland
}

\author{
Michał CZERNIELEWSKI ${ }^{1, *}$ \\ 1 Polish Academy of Sciences, Institute of Paleobiology, Twarda 51/55, 00-818 Warszawa, Poland
}

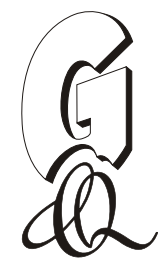

\begin{abstract}
Czernielewski, M., 2021. Gliridae (Rodentia) from the Villafranchian site of Węże 2 in southern Poland. Geological Quarterly,
\end{abstract} 65: 49, doi: 10.7306/gq.1618

Associate Editor: Michał Zatoń

\begin{abstract}
A fossil assemblage of dormice (Rodentia: Gliridae) was uncovered at the (Lower?) Villafranchian site of Węże 2 in southern Poland. Based on morphometric criteria, the diagnostic M1 and $\mathrm{m} 1$ specimens are assignable to Glis minor and Glis sackdillingensis, two species which differ only in the dimensions of their cheek teeth. The presence of dormice at Węże $2 \mathrm{im}-$ plies that the fossil assemblage of this site represents an at least partly wooded environment. The enamel structure in the glirids from Węże 2 is formed predominantly by radial enamel. A thin layer of lamellar enamel, occurring close to the enamel-dentine junction, may be present. Such a type of enamel structure is typical of the Myomorpha, the clade of rodents encompassing the Muroidea (the mouse-like rodents) and Gliridae.
\end{abstract}

Key words: Villafranchian, rodents, dormice, Węże, karst.

\section{INTRODUCTION}

This paper describes the fossil assemblage of dormice (Rodentia: Gliridae) uncovered at the Villafranchian (MN 16b?) site of Węże 2 in southern Poland. Although the site has been known since the early 1960s (Sulimski, 1962), much of the fossil material collected still awaits a systematic description. This study is part of a larger project intended to provide a comprehensive report on the rodent fauna of Węże 2. The data provided will contribute to current knowledge on the palaeobiogeography, palaeoecology and evolution of particular taxa.

The Gliridae (dormice) are an ancient family of omnivorous Old World rodents. They first appeared in the Eocene and underwent a major radiation during the Miocene. Nonetheless, at the end of the Miocene several phyletic lineages became extinct, which resulted in the modern genera being rather distantly related (Nadachowski, 1989; Daoud, 1993; Rose, 2006; Kurtén, 2007). The oldest glirid fossils from Poland are probably the Glirudinus sp. remains from the MN 5-6 (Lower Miocene) of Bełchatów (Kowalski, 1990).

Modern dormice are mostly associated with various kinds of arboreal and shrubby habitats, and generally are capable climbers, nesting in tree hollows or among branches. Caves are also sometimes inhabited and used as hibernacula, and areas with caves may be preferred by some species (Nadachowski, 1989

\footnotetext{
*E-mail: m.czernielewski@int.pl
}

Received: June 28, 2021; accepted: September 28, 2021; first published online: November 9, 2021
Kurtén, 2007; Kryštufek, 2010). It has been suggested that fossil dormice displayed greater ecological diversity than the surviving taxa (Nadachowski, 1989). Among recent genera, Eliomys differs from the typical Gliridae as it is known to thrive in open rocky environments and semi-desert areas of Northern Africa (Daoud, 1993; Amori et al., 2008).

There are nine extant genera of glirids comprising 29 species and grouped into three subfamilies (Holden, 2005). The Glis genus is today represented by the fat dormouse, G. glis. This species, as well as Glirulus japonicus (the Japanese dormouse) belong to the Glirinae subfamily, which is thought to have originated in the Oligocene (Holden, 2005; Kurtén, 2007; Holden and Levine, 2009). The evolutionary lineage G. minorG. sackdillingensis- G. glis is commonly inferred from the fossil record (Nadachowski, 1989; Daoud, 1993; Siori et al., 2014; Striczky and Pazonyi, 2014). Here I report the presence of G.m inor and G. sackdillingensis at the Villafranchian (MN16?) site of Węże 2 in southern Poland. Both species are considered to be associated with arboreal environments (de Bruijn, 1998; Popov, 2004; Hellmund and Ziegler, 2012; Siori et al., 2014; Striczky and Pazonyi, 2014; Colombero et al., 2017).

\section{GEOLOGICAL SETTING}

Węże 2 is a Villafranchian site situated on the NW slope of Zelce Hill $\left(51^{\circ} 06^{\prime} 00^{\prime \prime} \mathrm{N} 18^{\circ} 47^{\prime} 30^{\prime \prime} \mathrm{E} ; 228 \mathrm{~m}\right.$ a.s.I.) in the Wieluń Upland, near the village of Węże, in the vicinity of the town of Działoszyn, in Pajęczno County, southern Poland (Fig. 1). The site comprises a vertical karst crevice etched in Upper Jurassic (Oxfordian) limestone and infilled with fossiliferous sediment of terra rossa type. The crevice itself is a part of a larger karst cave 


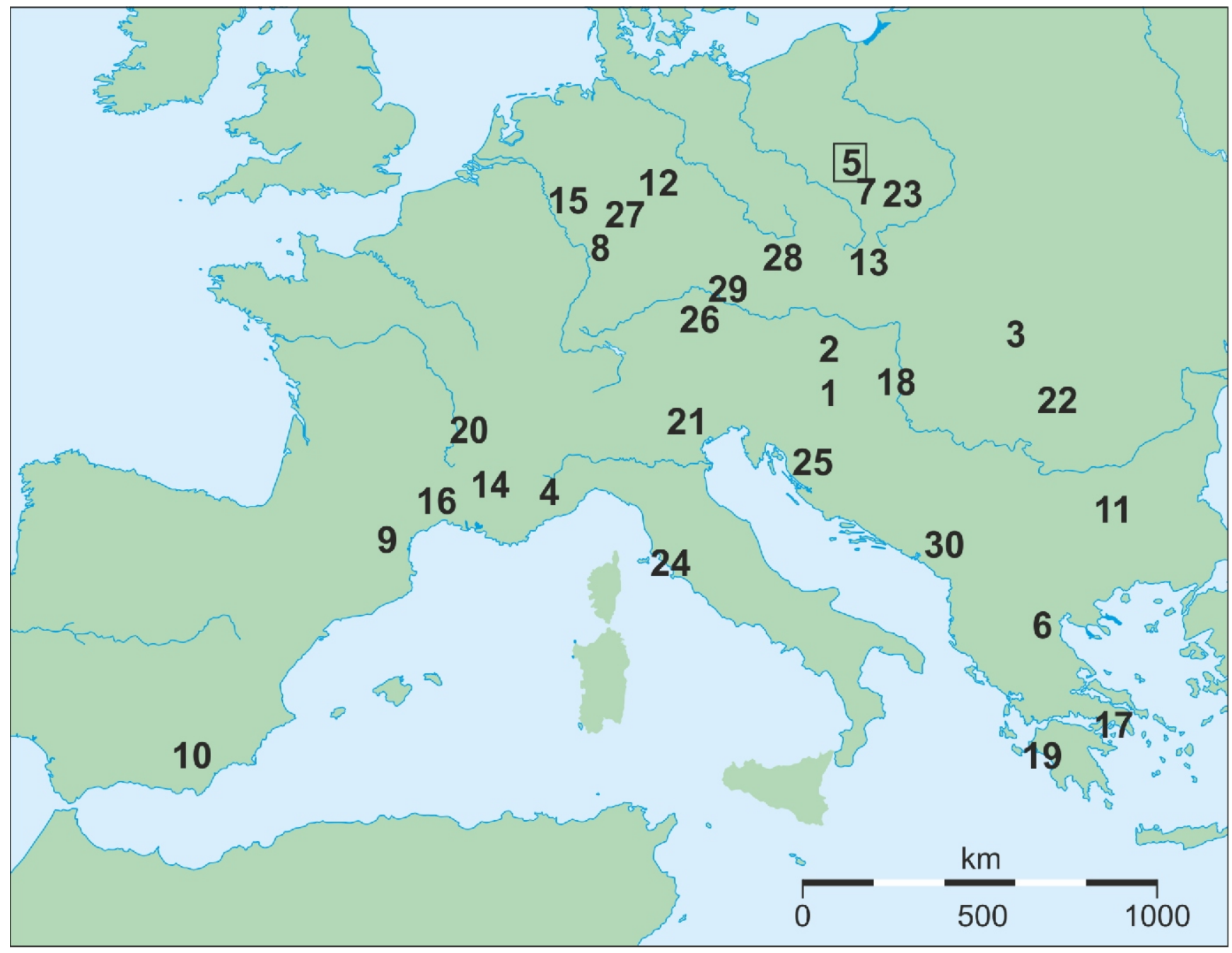

Fig. 1. Location of Węże 2 and other sites mentioned in Table 2, the Węże 2 area highlighted

1 - Oberdorf, Kohfidisch; 2 - Richardhof; 3 - Rudabánya, Osztramos, Kövesvárad, Tarkő, Uppony Rock Shelter 1; 4 - Moncucco Torinese; 5 - Mała Cave, Raciszyn 1, Węże 1, Węże 2; 6 - Komanos 1, Notio 1; 7 - Pańska Góra, Podlesice, Rębielice Królewskie, Kamyk, Kielniki, Żabia Cave; 8 - Wölfersheim; 9 - Mont Hélène; 10 - Moreda; 11 - Muselievo; 12 - Sondershausen; 13 - Vitošov; 14 - Grand Serre; 15 Hambach; 16 - Mas Rambault; 17 - Tourkovounia 1; 18 - Csarnóta, Somssich Hill 2, Beremend 14, Villány-Kalkberg-Nord; 19 - Kaiafas; 20 - Les Valerots; 21 - Monte la Mesa; 22 - Betfia; 23 - Kadzielnia, Kozi Grzbiet; 24 - Monte Argentario; 25 - Razvodje, Podumci; 26 Schernfeld; 27 - Untermassfeld; 28 - Chlum; 29 - Sackdillinger Cave; 30 - Trlica

system of the hill (Sulimski, 1962; Stefaniak, 1995; Stefaniak et al., 2020) and is located $\sim 150-200 \mathrm{~m}$ north from the better known Węże 1 site, which has been dated as MN 15 (e.g., Sulimski, 1964; Fostowicz-Frelik, 2007).

The Węże 2 site (abbreviated as W2) was discovered and initially explored between 1958 and 1961 by Sulimski, who detected an abundant fossil vertebrate fauna dominated by small mammal remains, whereas the large mammal fossils were rare and highly fragmented (Sulimski, 1962; Stefaniak et al., 2020). The terra rossa deposits ( $3.5 \mathrm{t}$ in total) were collected during fieldwork organized by the Department of Paleozoology (now: Institute of Paleobiology) PAS in Warsaw and the Department of Paleozoology of Wrocław University (Sulimski, 1962).

So far, the fossil remains have been described only in part, more detailed studies concerning cervids (Stefaniak, 1995; Stefaniak et al., 2020), rhinoceroses and elephantids (Stefaniak et al., 2020), and lagomorphs (Fostowicz-Frelik, 2007). The presence of diverse rodent and lipotyphlan faunas was mentioned (Sulimski, 1962; Nadachowski, 1989; Rzebik-Kowalska, 1989), but these were not studied in detail.
The accompanying, generally scarce reptilian remains included Lacerta sp., Anguis cf. fragilis, Ophisaurus pannonicus, Testudo sp. and Emys wermuthi, while amphibians were represented by rare and fragmented long bones of Rana sp. (Sulimski, 1962). The Węże 2 fossil assemblage is currently dated to the Late Pliocene (Lower Villafranchian) MN 16b zone (2.9-2.6 Ma) based on its faunal composition compared to the nearby site of Rębielice Królewskie 1 (Sulimski, 1962, 1964; Stefaniak, 1995; Stefaniak et al., 2020).

\section{MATERIAL AND METHODS}

The Glis material consists of isolated teeth and one mandible fragment with $\mathrm{m} 1-\mathrm{m} 2$ in situ (Fig. 2). All dental loci are represented in the sample, although the most numerous are $\mathrm{m} 1 / \mathrm{M} 1$ and $\mathrm{m} 2 / \mathrm{M} 2$, whereas $\mathrm{m} 3 / \mathrm{M} 3$ and $\mathrm{p} 4 / \mathrm{P} 4$ are underrepresented in the sample (see Table 1). The bias results most probably from the size factor, the premolars and the ultimate molars being the smallest teeth in the dental row, and thus 
A

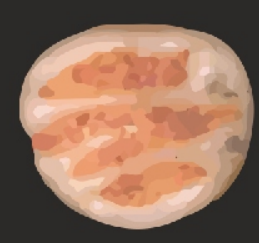

B

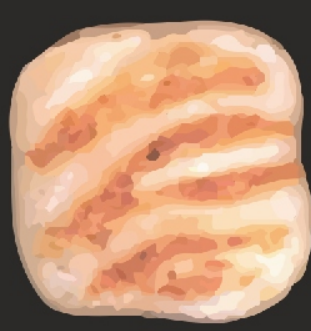

C

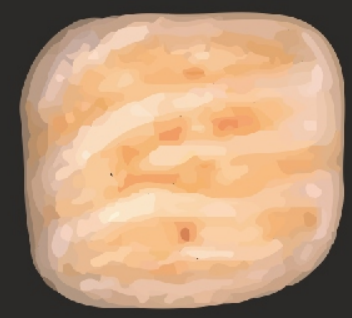

D
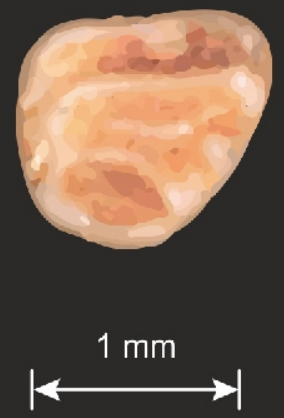

$\mathbf{E}$

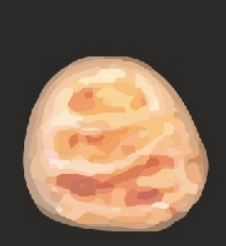

$\mathbf{F}$

$\mathbf{G}$

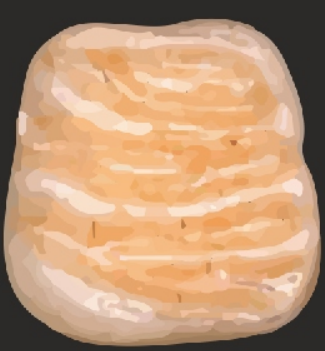

$\mathbf{J}$

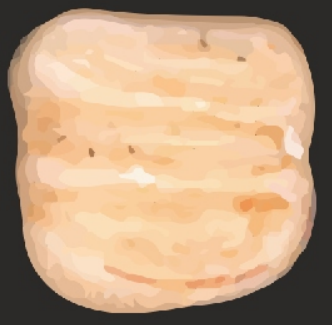

H

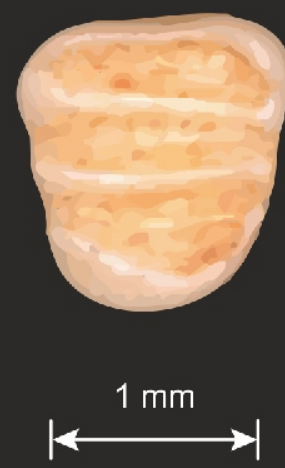

I
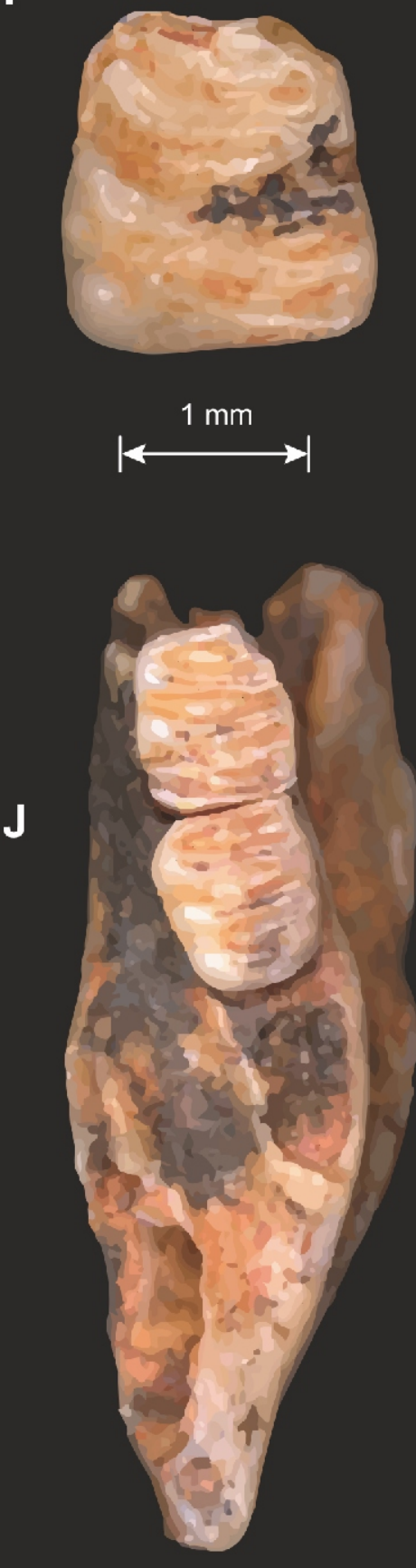

$\stackrel{1 \mathrm{~mm}}{\longrightarrow}$

Fig. 2. Glis ex gr. minor-sackdillingensis from Węże 2

A, C, D, E, G, H - G. ex gr. minor-sackdillingensis; B, F, J - G. minor; I- G. sackdillingensis; A - P4, B - M1, C - M2, D - M3, $\mathrm{E}-\mathrm{p} 4, \mathrm{~F}-\mathrm{m} 1, \mathrm{G}-\mathrm{m} 2, \mathrm{H}-\mathrm{m} 3, \mathrm{I}-\mathrm{m} 1, \mathrm{~J}$ - left mandible with $\mathrm{m} 1$ and $\mathrm{m} 2$; all in occlusal view 
Isolated teeth of Gliridae from Węże 2 - material and measurements

\begin{tabular}{|l|r|c|c|c|c|c|c|}
\hline $\begin{array}{c}\text { Species/ } \\
\text { tooth locus }\end{array}$ & $N$ & Length: min. & Length: mean & Length: max. & Width: min. & Width: mean & Width: max. \\
\hline \multicolumn{7}{|c|}{ Glis ex gr. minor-sackdillingensis } \\
\hline p4 & 6 & 0.87 & $0.99 \pm 0.0793$ & 1.06 & 0.89 & $0.97 \pm 0.0563$ & 1.02 \\
\hline m2 & 48 & 1.4 & $1.51 \pm 0.0606$ & 1.63 & 1.4 & $1.52 \pm 0.0610$ & 1.64 \\
\hline m3 & 11 & 1.3 & $1.42 \pm 0.0741$ & 1.56 & 1.3 & $1.33 \pm 0.0773$ & 1.45 \\
\hline P4 & 8 & 0.97 & $1.01 \pm 0.0294$ & 1.04 & 1.05 & $1.11 \pm 0.0353$ & 1.14 \\
\hline M2 & 29 & 1.35 & $1.45 \pm 0.0494$ & 1.56 & 1.48 & $1.59 \pm 0.0538$ & 1.7 \\
\hline M3 & 4 & 1.17 & $1.2 \pm 0.025$ & 1.23 & 1.31 & $1.34 \pm 0.0424$ & 1.4 \\
\hline \multicolumn{7}{|c|}{ Glis minor } \\
\hline m1 & 61 & 1.34 & $1.52 \pm 0.068$ & 1.63 & 1.32 & $1.48 \pm 0.0731$ & 1.65 \\
\hline M1 & 62 & 1.38 & $1.5 \pm 0.0557$ & 1.66 & 1.32 & $1.49 \pm 0.0611$ & 1.62 \\
\hline \multicolumn{7}{|c|}{ Glis sackdillingensis } \\
\hline m1 & 6 & 1.65 & $1.7 \pm 0.0715$ & 1.84 & 1.53 & $1.58 \pm 0.0450$ & 1.66 \\
\hline
\end{tabular}

easier to overlook during collecting and preparation. The morphology of the teeth is typical of Glis teeth described from coeval localities in Poland (Kowalski, 1960b, 1963; Daoud, 1993).

The remains were recovered from the bone breccia site of Węże 2 by hand picking. Some larger portions of more calcified sediment were dissolved using acetic acid and then the residue was sifted. The specimens were examined, measured and photographed with the Keyence VHX 900-F Digital Microscope System.

The glirid dental terminology follows Striczky and Pazonyi (2014) and is illustrated in Figure 3. The enamel microstructure of the cheek teeth was made visible using the method described in Fostowicz-Frelik et al. (2012). It was then studied under SEM (Philips XL20 at the Institute of Paleobiology PAS). The material is housed in the collection of the Institute of Paleobiology PAS (abbreviated ZPAL).

\section{SYSTEMATIC PALAEONTOLOGY}

Order Rodentia Bowdich, 1821

Family Gliridae Muirhead, 1819

Subfamily Glirinae Thomas, 1897

Genus Glis Brisson, 1762

Glis sackdillingensis (Heller, 1930)

Glis minor Kowalski, 1956

\section{MATERIAL}

Glis sackdillingensis, isolated teeth: $6 \mathrm{~m} 1$ (ZPAL M.VIII/b/ G2/1-6).

Glis minor, isolated teeth: $61 \mathrm{~m} 1$ (ZPAL M.VIII/b/G1/ 16-76), 62 M1 (ZPAL M.VIII/b/G1/77-138); a fragment of the left mandible with m1-m2 in situ (ZPAL M.VIII/b/G1/1).

Glis ex gr. sackdillingensis-minor, isolated teeth: $6 \mathrm{p} 4$ (ZPAL M.VIII/b/G1/2-7), 8 P4 (ZPAL M.VIII/b/G1/8-15), 48 m2 (ZPAL M.VIII/b/G1/139-186), 29 M2 (ZPAL M.VIII/b/G1/ 187-215), $11 \mathrm{~m} 3$ (ZPAL M.VIII/b/G1/216-226) and $4 \mathrm{M3}$ (ZPAL M.VIII/b/G1/227-230).

\section{Occlusal surface of M1}

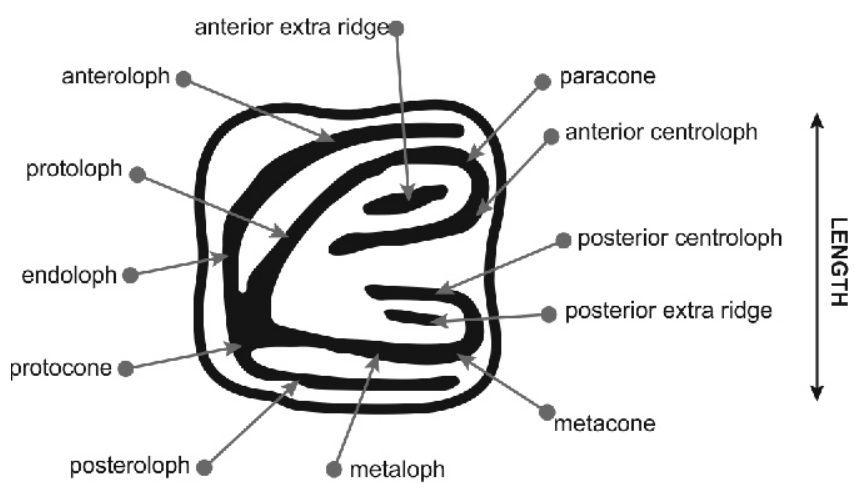

\section{Occlusal surface of $\mathrm{m} 1$}

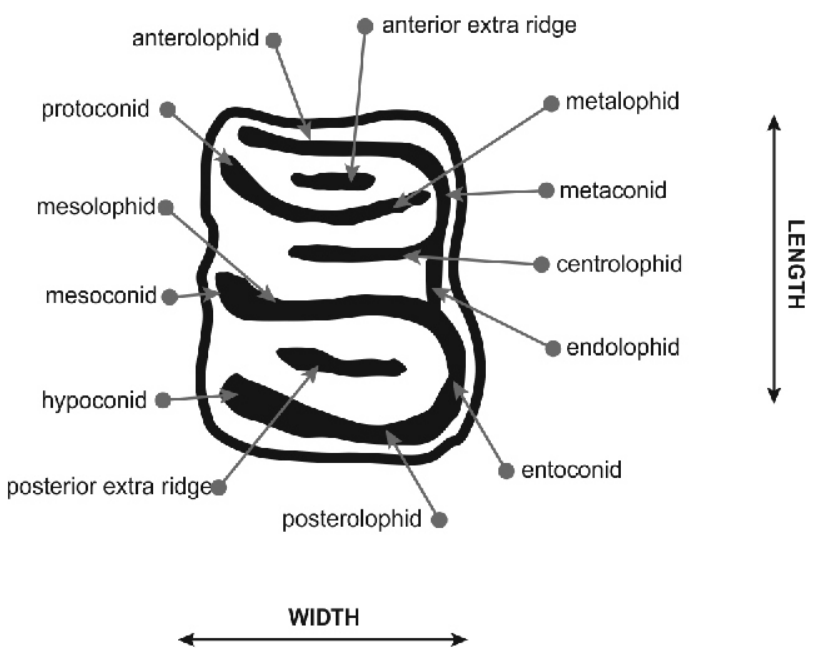

Fig. 3. Schematic drawings of the M1 and $m 1$ occlusal surface of Glis ex gr. minor-sackdillingensis (after Striczky and Pazonyi, 2014, modified) 
DESCRIPTION

\author{
Glis sackdillingensis \\ $\mathrm{m} 1$ (Fig. 2F)
}

A vaguely rectangular, anteriorly narrowed tooth. The anterolophid, the metalophid, the centrolophid, the mesolophid and the posterolophid are present. The metalophid, the mesolophid and the posterolophid are clearly curved. Extra ridges may be present (Fig. 3). In W2 the length of the tooth ranges from 1.65 to $1.84 \mathrm{~mm}$ and the width from 1.53 to $1.66 \mathrm{~mm}$ (Table 1 and Fig. 4D).

\section{Glis minor}

M1 (Fig. 2B)

A squarish tooth with rounded corners. The anteroloph, the protoloph, the anterior centroloph, the metaloph and the posteroloph are present. The anteroloph is clearly rounded. Extra ridges may be present (Fig. 3). In W2 the length of the tooth ranges from 1.38 to $1.66 \mathrm{~mm}$, and the width from 1.32 to $1.62 \mathrm{~mm}$ (Table 1 and Fig. 4C).

$$
\text { m1 (Fig. 2F) }
$$

Morphologically indistinguishable from G. sackdillingensis (Fig. 3). The anterolophid, the metalophid, the centrolophid, the mesolophid and the posterolophid are present. The length of the teeth from $\mathrm{W} 2$ ranges from 1.34 to $1.63 \mathrm{~mm}$ and the width from 1.32 to $1.65 \mathrm{~mm}$ (Table 1 and Fig. 4D).

\section{Glis ex gr. minor-sackdillingensis}

$$
\text { P4 (Fig. 2A) }
$$

The outline of the occlusal surface is roughly oval. The anteroloph, the protoloph, the metaloph, and the posteroloph are present. The length of the Węże 2 specimens ranges from 0.97 to $1.04 \mathrm{~mm}$, and the width from 1.05 to $1.14 \mathrm{~mm}$ (Table 1 and Fig. 4A). These specimens, as are all the other non-diagnostic teeth, are attributed to G. ex gr. minor-sackdillingensis as an exact specific assignment is not possible with adequate certainty and both species are present at the site (see Striczky and Pazonyi, 2014).

$$
\text { M2 (Fig. 2C) }
$$

A broad, squarish tooth with its corners slightly rounded The anteroloph, the protoloph, the anterior centroloph, the metaloph and the posteroloph are present. The length of the Węże 2 specimens ranges from 1.35 to $1.56 \mathrm{~mm}$, and the width from 1.48 to $1.7 \mathrm{~mm}$ (Table 1 and Fig. 4E).
M3 (Fig. 2D)

It is approximately triangular in shape, posteriorly narrowed. The anteroloph, the protoloph, the anterior centroloph, the metaloph and the posteroloph are present, as well as a residual posterior centroloph, located posterior to the anterior centroloph. The length of the M3 specimens collected from Węże 2 ranges from 1.17 to $1.23 \mathrm{~mm}$ and the width from 1.31 to $1.4 \mathrm{~mm}$ (Table 1 and Fig. 4G).

$$
\text { p4 (Fig. 2E) }
$$

The shape of the occlusal surface resembles a circular triangle. It is also the smallest of the teeth (Fig. 4B). The anterolophid, the metalophid, the mesolophid and the posterolophid are present. The length of the Węże 2 specimens ranges from 0.87 to $1.06 \mathrm{~mm}$ and the width from 0.89 to $1.02 \mathrm{~mm}$ (Table 1 and Fig. 4B).

$$
\text { m2 (Fig. 2G) }
$$

A vaguely rectangular tooth, posteriorly narrowed. The anterolophid, the metalophid, the centrolophid, the mesolophid and the posterolophid are present. The length of the teeth collected at Węże 2 ranges from 1.4 to $1.63 \mathrm{~mm}$ and the width from 1.4 to $1.64 \mathrm{~mm}$ (Table 1 and Fig. 4F).

$$
\text { m3 (Fig. 2H) }
$$

It is similar to $\mathrm{m} 2$ but still more narrowed posteriorly. The anterolophid, the metalophid, the centrolophid, the mesolophid and the posterolophid are present. The length of the Węże 2 specimens ranges from 1.3 to $1.56 \mathrm{~mm}$ and the width from 1.3 to $1.45 \mathrm{~mm}$ (Table 1 and Fig. $4 \mathrm{H}$ ).

Preliminary observations of the Węże 2 material show the ridges at the occlusal surfaces of the cheek teeth in Glis ex gr. minor-sackdillingensis as being low and delicate. The enamel layer covering the circumference of the teeth and the ridges is relatively thin, ranging from 38 to $93 \mu \mathrm{m}$. It is usually thickest along the ridges and at the lingual and buccal margins of the teeth. Also, its thickness changes from the root to the crown (in vertical sections, as demonstrated by Koenigswald, 2004). The most even enamel layer is observed in p4 (Fig. 6).

\section{REMARKS}

In the inferred G. minor-G. sackdillingensis-G. glis lineage a general increase in molar dimensions is supposed to be observed in the fossil record (Kowalski, 1956; Daoud, 1993; Striczky and Pazonyi, 2014). The cheek teeth of G. minor are morphologically indistinguishable from those of $G$. sackdillingensis (Striczky and Pazonyi, 2014). Instead, the two species either have been arbitrarily distinguished by the size of their molars, or by their supposedly complementary strati- 

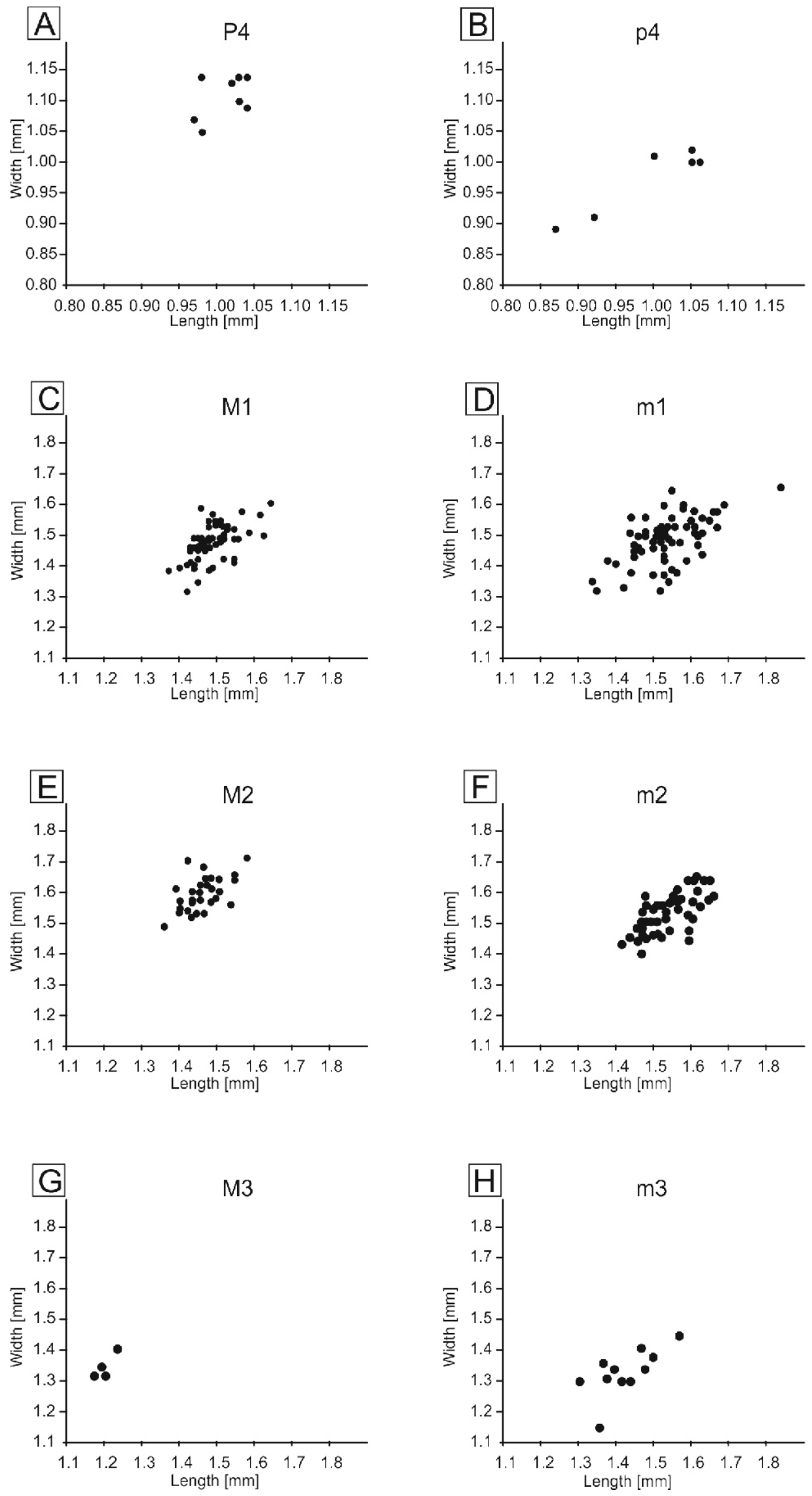

Fig. 4. Bivariate plots showing the measurements of Glis teeth from Węże 2 


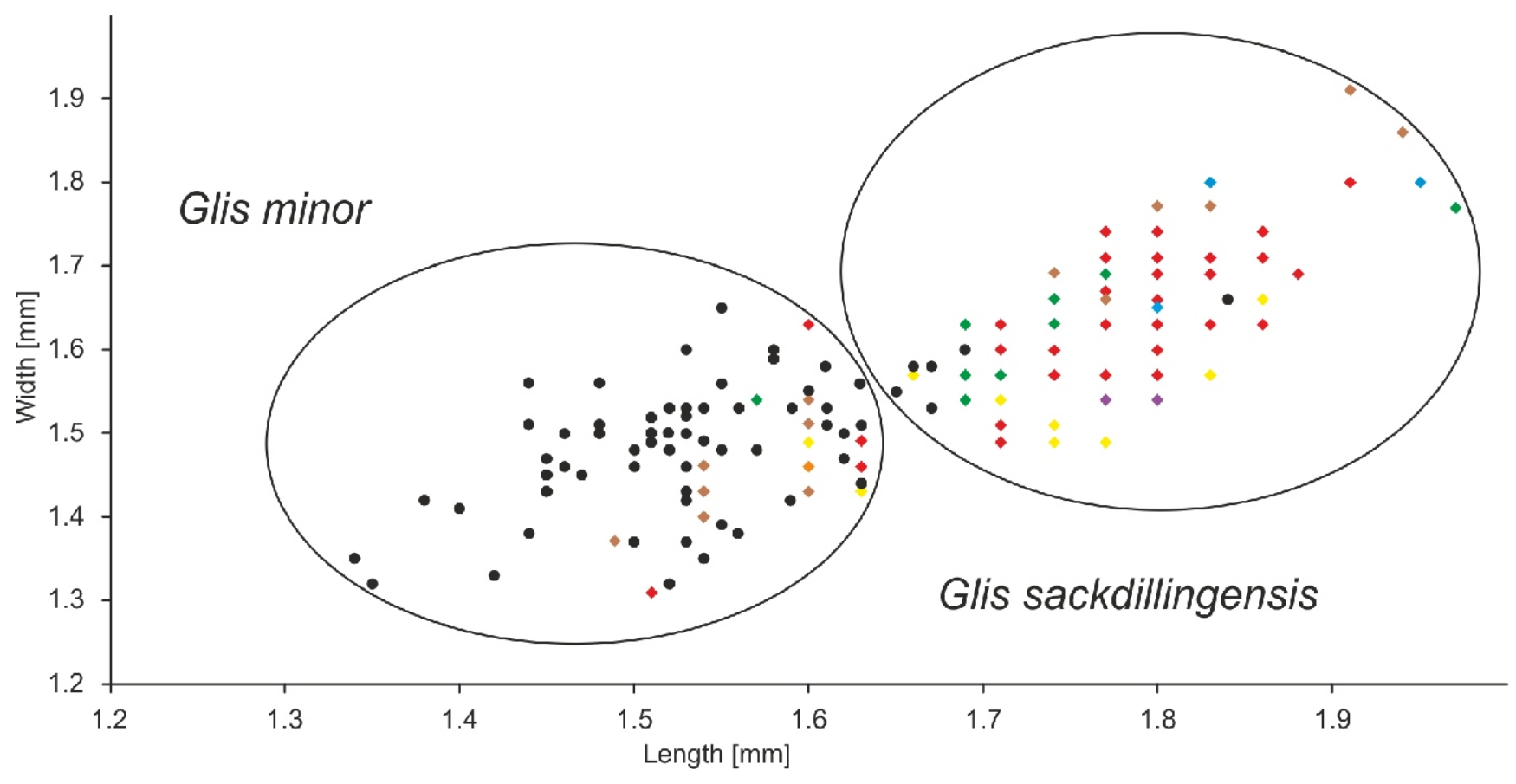

Fig. 5. Bivariate plots showing the measurements of G. minor and G. sackdillingensis $\mathrm{m} 1$ specimens from Węże 2 (black circles) and several central European sites studied by Striczky and Pazonyi 2014 (diamond shapes)

Brown - Somssich Hill 2; yellow - Osztramos 1; orange - Osztramos 1/E; red - Tarkő; green - Kövesvárad; violet - Uppony Rock Shelter 1; blue - Sackdillinger Cave

graphic ranges, with geologically older material being routinely assigned to G. minor (Table 2). Using statistical tools, Striczky and Pazonyi (2014) have established that in G. minor the length of $\mathrm{m} 1$ is $<1.65 \mathrm{~mm}$ (Fig. 5) while the width of $\mathrm{M} 1$ is $<1.7 \mathrm{~mm}$.

\section{DISCUSSION}

The genus Glis, which represents the Glirinae lineage of the Gliridae family, is considered to have originated in the Middle Oligocene of Anatolia and to be descended from Gliravus (Daams and de Bruijn, 1995). Several extinct and one extant species (G. glis) are known (Daams and de Bruijn, 1995; Holden, 2005; Holden and Levine, 2009; Kryštufek, 2010). The stratigraphic range of the G. minor-sackdillingensis complex spans from the late Early Miocene to the late Early Pleistocene and both forms are known predominantly from Central Europe, with clusters of sites located in Austria, Hungary and Poland (Table 2 and Fig. 1). G. minor was first described by Kowalsk (1956) as G. sackdillingensis minor, based on the material from Podlesice, as the dimensions of the Podlesice form "are distinctly smaller than all the corresponding dimensions of specimens from Germany, which strongly suggests its establishment as a separate subspecies". This smaller form was then raised to the rank of a species (G. minor) by Kretzoi (1959), a decision which was supported by Kowalski (1963).

Two specimens of $\mathrm{p} 4$ seem significantly smaller than the rest (Fig. 4B) but specimens narrower than $0.95 \mathrm{~mm}$ were already known from Węże 1 (Kowalski, 1963) and Sondershausen, and the measurements of the Glis teeth from Węże 1, Węże 2 and Rębielice Królewskie often fall quite close to the lower end of the typical G. ex gr. sackdillingensis-minor ranges (Hellmund and Ziegler, 2012). Furthermore, Kowalski, in his description of some fossil rodent fauna from Rębielice Królewskie, reported a finding of a small $(0.9 \mathrm{~mm}$ long, $0.9 \mathrm{~mm}$ wide) detached $\mathrm{p} 4$ that he classified as cf. Glis sp. and considered to possibly represent "a thus far unknown, very minute form of the genus Glis Brisson" (Kowalski, 1960b).

G. minor is considered to be the immediate ancestor of $G$. sackdillingensis which in turn is thought to have evolved into the modern G. glis (Nadachowski, 1989; Daoud, 1993; Siori et al., 2014; Striczky and Pazonyi, 2014). The direct ancestor of $G$. minor has not been recognized. Although a synonymy between G. sackdillingensis and G. minor has been proposed (de Bruijn and van der Meulen, 1975), this suggestion has not generally been followed and "complementary stratigraphic ranges" have been cited as an argument in favour of keeping the specific status of the alleged smaller form (Popov, 2004). However, when the criteria elaborated by Striczky and Pazonyi (2014) are applied to the previously described G. minor / G. sackdillingensis material, there seems to be little such complementarity (see Table 2). At the same time, the statistical analyses of Striczky and Pazonyi (2014) seem to support the existence of two separate species, distinguishable only by morphometric criteria.

So far, the incisor enamel of the Glires (rodents and lagomorphs) has been studied more extensively than that of the molars. In the case of the Gliridae, Koenigswald (1993) provided a detailed study of their incisor enamel structure only. A more comprehensive study by Koenigswald (2004) provided a survey of the molar enamel structure in both fossil and extant rodents, concerning three types of schmelzmuster (spatial organization of enamel types) and their distribution across the phylogenetic tree. The Gliridae are virtually not mentioned there, apart from Muscardinus and Leithia, a large, insular form from the Pleistocene of the Mediterranean. 
Occurrences of Glis ex gr. minor-sackdillingensis

\begin{tabular}{|c|c|c|c|c|}
\hline No. & Locality & Age & Species detected & References \\
\hline 1. & $\begin{array}{l}\text { Oberdorf } \\
\text { (Austria) }\end{array}$ & MN 4 & G. minor & de Bruijn (1998) \\
\hline 2. & $\begin{array}{c}\text { Richardhof-Golfplatz } \\
\text { (Austria) }\end{array}$ & MN 9 & $\begin{array}{c}\text { G. minor } \\
{ }^{*} \text { G. sackdillingensis }\end{array}$ & $\begin{array}{c}\text { Daxner-Höck and Höck } \\
(2009)\end{array}$ \\
\hline 3. & $\begin{array}{l}\text { Rudabánya } \\
\text { (Hungary) }\end{array}$ & MN 9 & $\begin{array}{c}\text { G. minor, } \\
{ }^{*} \text { G. sackdillingensis }\end{array}$ & Daxner-Höck (2005) \\
\hline 4. & $\begin{array}{l}\text { Richardhof-Wald } \\
\text { (Austria) }\end{array}$ & MN 10 & $\begin{array}{c}\text { G. minor } \\
\left({ }^{*}=\text { G. sackdillingensis }\right)\end{array}$ & $\begin{array}{c}\text { Daxner-Höck and Höck } \\
(2009)\end{array}$ \\
\hline 5. & $\begin{array}{l}\text { Kohfidisch } \\
\text { (Austria) }\end{array}$ & MN 11 & G. minor & $\begin{array}{c}\text { Daxner-Höck and Höck } \\
(2009)\end{array}$ \\
\hline 6. & $\begin{array}{c}\text { Moncucco Torinese } \\
\text { (Italy) }\end{array}$ & $\begin{array}{c}\mathrm{MN} 13 \\
(5.41-5.33 \mathrm{Ma}) \\
\end{array}$ & $\begin{array}{c}\text { G. minor, } \\
{ }^{*} G \text {. sackdillingensis }\end{array}$ & $\begin{array}{l}\text { Colombero et al. (2014, } \\
2017)\end{array}$ \\
\hline 7. & $\begin{array}{l}\text { Mała Cave } \\
\text { (Poland) }\end{array}$ & MN 14 & $\begin{array}{c}\text { G. minor, } \\
{ }^{*} \text { G. sackdillingensis }\end{array}$ & $\begin{array}{c}\text { Sulimski et al. (1979); } \\
\text { Nadachowski et al. (1989) }\end{array}$ \\
\hline 8. & $\begin{array}{c}\text { Komanos } 1 \\
\text { (Greece) }\end{array}$ & Late Turolian & (?) G. minor & Hordijk and de Bruijn (2009) \\
\hline 9. & $\begin{array}{l}\text { Notio } 1 \\
\text { (Greece) }\end{array}$ & Late Turolian & G. minor & Hordijk and de Bruijn (2009) \\
\hline 10. & $\begin{array}{l}\text { Pańska Góra } \\
\text { (Poland) }\end{array}$ & Early Pliocene & $\begin{array}{c}\text { G. minor, } \\
{ }^{*} \text { G. sackdillingensis }\end{array}$ & $\begin{array}{l}\text { Bednarczyk (1993); } \\
\text { Daoud (1993) }\end{array}$ \\
\hline 11. & $\begin{array}{c}\text { Wölfersheim } \\
\text { (Germany) }\end{array}$ & Early Pliocene & G. minor & Dahlmann (2001) \\
\hline 12. & $\begin{array}{l}\text { Podlesice } \\
\text { (Poland) }\end{array}$ & MN 14 & $\begin{array}{c}\text { G. minor, } \\
{ }^{*} \text { G. sackdillingensis }\end{array}$ & $\begin{array}{c}\text { Kowalski (1956, 1963); } \\
\text { Sulimski et al. (1979); } \\
\text { Daoud (1993) }\end{array}$ \\
\hline 13. & $\begin{array}{l}\text { Mont Hélène } \\
\text { (France) }\end{array}$ & Ruscinian & $\begin{array}{l}\text { G. sackdillingensis } \\
\left({ }^{*}=\text { G. minor }\right)\end{array}$ & Aguilar et al. (1986) \\
\hline 14. & $\begin{array}{l}\text { Moreda } \\
\text { (Spain) }\end{array}$ & Ruscinian & G. sackdillingensis & Martin-Suarez (1998) \\
\hline 15. & $\begin{array}{l}\text { Muselievo } \\
\text { (Bulgaria) } \\
\end{array}$ & MN 15 & G. minor & Popov (2004) \\
\hline 16. & $\begin{array}{l}\text { Raciszyn } 1 \\
\text { (Poland) } \\
\end{array}$ & MN 15 & (?) G. minor & $\begin{array}{c}\text { Nadachowski (1989); } \\
\text { Nadachowski et al. (1989) } \\
\end{array}$ \\
\hline 17. & $\begin{array}{c}\text { Sondershausen } \\
\text { (Germany) }\end{array}$ & MN 15 & $\begin{array}{c}\text { G. minor, } \\
{ }^{*} G \text {. sackdillingensis }\end{array}$ & Hellmund and Ziegler (2012) \\
\hline 18. & $\begin{array}{l}\text { Węże } 1 \\
\text { (Poland) }\end{array}$ & MN 15 & $\begin{array}{c}\text { G. minor, } \\
{ }^{*} \mathrm{G} \text {. sackdillingensis }\end{array}$ & $\begin{array}{c}\text { Sulimski (1964); } \\
\text { Daoud (1993); } \\
\text { Stefaniak et al. (2020); }\end{array}$ \\
\hline 19. & $\begin{array}{l}\text { Vitošov } \\
\text { (Czechia) }\end{array}$ & MN 15/16 & $\begin{array}{c}\text { G. minor } \\
\left({ }^{*}=\text { G. sackdillingensis }\right)\end{array}$ & Čermák et. al. (2016) \\
\hline 20. & $\begin{array}{l}\text { Grand Serre } \\
\text { (France) }\end{array}$ & Late Pliocene & G. sackdillingensis & Aguilar et al. (1993) \\
\hline 21. & $\begin{array}{l}\text { Hambach } \\
\text { (Germany) }\end{array}$ & Late Pliocene & $\begin{array}{c}\text { G. minor } \\
\left({ }^{*}=\text { G. sackdillingensis }\right)\end{array}$ & Mörs et al. (1998) \\
\hline 22. & $\begin{array}{l}\text { Mas Rambault } \\
\text { (France) }\end{array}$ & Late Pliocene & G. sackdillingensis & Aguilar et al. (2002) \\
\hline 23. & $\begin{array}{l}\text { Rębielice Królewskie } \\
\text { (Poland) }\end{array}$ & MN 16 & $\begin{array}{l}\text { G. minor, } \\
{ }^{*} \text { G. sackdillingensis }\end{array}$ & $\begin{array}{c}\text { Kowalski (1963); } \\
\text { Daoud (1993); } \\
\text { Stefaniak et al. (2020) } \\
\end{array}$ \\
\hline 24. & $\begin{array}{l}\text { Tourkovounia } 1 \\
\text { (Greece) }\end{array}$ & MN 16 & (?) G. sackdillingensis & Koufos (2001) \\
\hline 25. & $\begin{array}{l}\text { Węże } 2 \\
\text { (Poland) }\end{array}$ & MN $16 ?$ & $\begin{array}{c}\text { G. minor, } \\
\text { G. sackdillingensis }\end{array}$ & $\begin{array}{c}\text { Sulimski (1962); } \\
\text { Stefaniak et al. (2020); }\end{array}$ \\
\hline 26. & $\begin{array}{l}\text { Csarnóta } \\
\text { (Hungary) }\end{array}$ & $\begin{array}{l}\text { Late Pliocene/Early Pleisto- } \\
\text { cene }\end{array}$ & (?) G. minor & $\begin{array}{l}\text { Kretzoi (1959); } \\
\text { Jánossy (1986) }\end{array}$ \\
\hline 27. & $\begin{array}{l}\text { Kamyk } \\
\text { (Poland) }\end{array}$ & $\begin{array}{l}\text { Late Pliocene/Early Pleisto- } \\
\text { cene }\end{array}$ & $\begin{array}{l}{ }^{*} \text { G. minor, } \\
\text { G. sackdillingensis }\end{array}$ & $\begin{array}{c}\text { Kowalski (1960a, 1963); } \\
\text { Daoud (1993) }\end{array}$ \\
\hline
\end{tabular}


Tab. 2 cont.

\begin{tabular}{|c|c|c|c|c|}
\hline 28. & $\begin{array}{l}\text { Osztramos } 1 \\
\text { (Hungary) }\end{array}$ & $\begin{array}{l}\text { Late Pliocene/Early Pleisto- } \\
\text { cene }\end{array}$ & $\begin{array}{c}\text { G. minor, } \\
\text { G. sackdillingensis }\end{array}$ & $\begin{array}{l}\text { Jánossy (1986); } \\
\text { Striczky and Pazonyi (2014) }\end{array}$ \\
\hline 29. & $\begin{array}{l}\text { Osztramos 1/E } \\
\text { (Hungary) }\end{array}$ & $\begin{array}{l}\text { Late Pliocene/Early Pleisto- } \\
\text { cene }\end{array}$ & $\begin{array}{c}\text { G. minor, } \\
\text { G. sackdillingensis }\end{array}$ & Striczky and Pazonyi (2014) \\
\hline 30. & $\begin{array}{c}\text { Osztramos } 7 \\
\text { (Hungary) }\end{array}$ & $\begin{array}{l}\text { Late Pliocene/Early Pleisto- } \\
\text { cene }\end{array}$ & (?) G. minor & Jánossy (1986) \\
\hline 31. & $\begin{array}{c}\text { Osztramos } 9 \\
\text { (Hungary) }\end{array}$ & $\begin{array}{l}\text { Late Pliocene/Early Pleisto- } \\
\text { cene }\end{array}$ & G. minor & Striczky and Pazonyi (2014) \\
\hline 32. & $\begin{array}{l}\text { Kaiafas } \\
\text { (Greece) }\end{array}$ & MNQ 19 & (?) G. sackdillingensis & Koufos (2001) \\
\hline 33. & $\begin{array}{l}\text { Les Valerots } \\
\text { (France) }\end{array}$ & Early Biharian & G. minor & Chaline (1972) \\
\hline 34. & $\begin{array}{l}\text { Monte la Mesa } \\
\text { (Italy) }\end{array}$ & Early Biharian & G. sackdillingensis & Marchetti et al. (2000) \\
\hline 35. & $\begin{array}{c}\text { Betfia } \\
\text { (Romania) }\end{array}$ & Biharian & $\begin{array}{c}\text { (?) G. cf. minor, } \\
\text { (?) G. sackdillingensis }\end{array}$ & Terzea (1996) \\
\hline 36. & $\begin{array}{l}\text { Beremend } 14 \\
\text { (Hungary) }\end{array}$ & Early Pleistocene & $\begin{array}{c}\text { G. minor, } \\
{ }^{*} \text { G. sackdillingensis }\end{array}$ & Pazonyi et al. (2016) \\
\hline 37. & $\begin{array}{l}\text { Kadzielnia } \\
\text { (Poland) }\end{array}$ & Early Pleistocene & $\begin{array}{c}{ }^{*} \text { G. minor, } \\
\text { G. sackdillingensis }\end{array}$ & $\begin{array}{c}\text { Daoud (1993); } \\
\text { Urban et al. (2019) }\end{array}$ \\
\hline 38. & $\begin{array}{l}\text { Kielniki 3A } \\
\text { (Poland) }\end{array}$ & $\begin{array}{c}\text { Early Pleistocene } \\
\text { (Early Biharian) }\end{array}$ & (?) G. sackdillingensis & $\begin{array}{c}\text { Nadachowski (1989); } \\
\text { Nadachowski et al. (1989) }\end{array}$ \\
\hline 39. & $\begin{array}{l}\text { Kielniki } 1 \\
\text { (Poland) }\end{array}$ & $\begin{array}{l}\text { Early Pleistocene } \\
\text { (Late Biharian) }\end{array}$ & $\begin{array}{l}\text { G. sackdillingensis } \\
\left({ }^{*}=\text { G. minor }\right)\end{array}$ & $\begin{array}{c}\text { Nadachowski (1989); } \\
\text { Nadachowski et al. (1989); } \\
\text { Daoud (1993) }\end{array}$ \\
\hline 40. & $\begin{array}{l}\text { Monte Argentario } \\
\text { (Italy) }\end{array}$ & Early Pleistocene & (?) G. sackdillingensis & Siori et al. (2014) \\
\hline 41. & $\begin{array}{c}\text { Osztramos } 3 \\
\text { (Hungary) }\end{array}$ & Early Pleistocene & (?) G. sackdillingensis & Jánossy (1986) \\
\hline 42. & $\begin{array}{l}\text { Osztramos } 14 \\
\text { (Hungary) }\end{array}$ & Early Pleistocene & (?) G. sackdillingensis & Jánossy (1986) \\
\hline 43. & $\begin{array}{l}\text { Razvodje } \\
\text { (Croatia) }\end{array}$ & Early Pleistocene & (?) G. sackdillingensis & $\begin{array}{c}\text { Paunovic and Rabeder } \\
(1996)\end{array}$ \\
\hline 44. & $\begin{array}{l}\text { Schernfeld } \\
\text { (Germany) }\end{array}$ & Early Pleistocene & $\begin{array}{c}{ }^{*} \text { G. minor, } \\
\text { G. sackdillingensis }\end{array}$ & Dehm (1962) \\
\hline 45. & $\begin{array}{l}\text { Untermassfeld } \\
\text { (Germany) }\end{array}$ & Early Pleistocene & G. sackdillingensis & Maul (2001) \\
\hline 46. & $\begin{array}{c}\text { Villány-Kalkberg-Nord } \\
\text { (Hungary) }\end{array}$ & Early Pleistocene & (?) G. sackdillingensis & Jánossy (1986) \\
\hline 47. & $\begin{array}{l}\text { Żabia Cave } \\
\text { (Poland) }\end{array}$ & Early Pleistocene & (?) G. sackdillingensis & $\begin{array}{c}\text { Stefaniak et al. (2009); } \\
\text { Nadachowski et al. (2011) }\end{array}$ \\
\hline 48. & $\begin{array}{c}\text { Somssich Hill } 2 \\
\text { (Hungary) }\end{array}$ & Late Early Pleistocene & $\begin{array}{c}\text { G. minor, } \\
\text { G. sackdillingensis }\end{array}$ & Striczky and Pazonyi (2014) \\
\hline 49. & $\begin{array}{l}\text { Chlum } 4 \\
\text { (Czechia) }\end{array}$ & Early/Middle Pleistocene & (?) G. sackdillingensis & Horáček et al. (2016) \\
\hline 50. & $\begin{array}{l}\text { Kozi Grzbiet } \\
\text { (Poland) }\end{array}$ & Early/Middle Pleistocene & $\begin{array}{l}\text { G. minor*, } \\
\text { G. sackdillingensis }\end{array}$ & $\begin{array}{c}\text { Nadachowski (1989); } \\
\text { Nadachowski et al. (1989); } \\
\text { Daoud (1993) }\end{array}$ \\
\hline 51. & $\begin{array}{l}\text { Podumci } \\
\text { (Croatia) }\end{array}$ & Early Middle Pleistocene & G. sackdillingensis & Malez and Rabeder (1984) \\
\hline 52. & $\begin{array}{c}\text { Sackdillinger Cave } \\
\text { (Germany) }\end{array}$ & Early Middle Pleistocene & G. sackdillingensis & $\begin{array}{c}\text { Heller (1930); } \\
\text { Striczky and Pazonyi (2014) }\end{array}$ \\
\hline 53. & $\begin{array}{c}\text { Trlica } \\
\text { (Montenegro) }\end{array}$ & Early Middle Pleistocene & (?) G. sackdillingensis & Agadzhanian et al. (2017) \\
\hline 54. & $\begin{array}{c}\text { Kövesvárad } \\
\text { (Hungary) }\end{array}$ & Middle Pleistocene & $\begin{array}{c}\text { G. minor, } \\
\text { G. sackdillingensis }\end{array}$ & Striczky and Pazonyi (2014) \\
\hline 55. & $\begin{array}{c}\text { Tarkö } \\
\text { (Hungary) }\end{array}$ & Middle Pleistocene & $\begin{array}{c}\text { G. minor, } \\
\text { G. sackdillingensis }\end{array}$ & $\begin{array}{c}\text { Jánossy (1986); } \\
\text { Striczky and Pazonyi (2014) }\end{array}$ \\
\hline 56. & $\begin{array}{c}\text { Uppony Rock Shelter } 1 \\
\text { (Hungary) }\end{array}$ & Middle Pleistocene & $\begin{array}{c}\text { G. minor, } \\
\text { G. sackdillingensis }\end{array}$ & $\begin{array}{c}\text { Jánossy (1986) } \\
\text { Striczky and Pazonyi (2014) }\end{array}$ \\
\hline
\end{tabular}

* - revised according to the criteria given by Striczky and Pazonyi (2014); (?) - measurements of diagnostic teeth not provided 

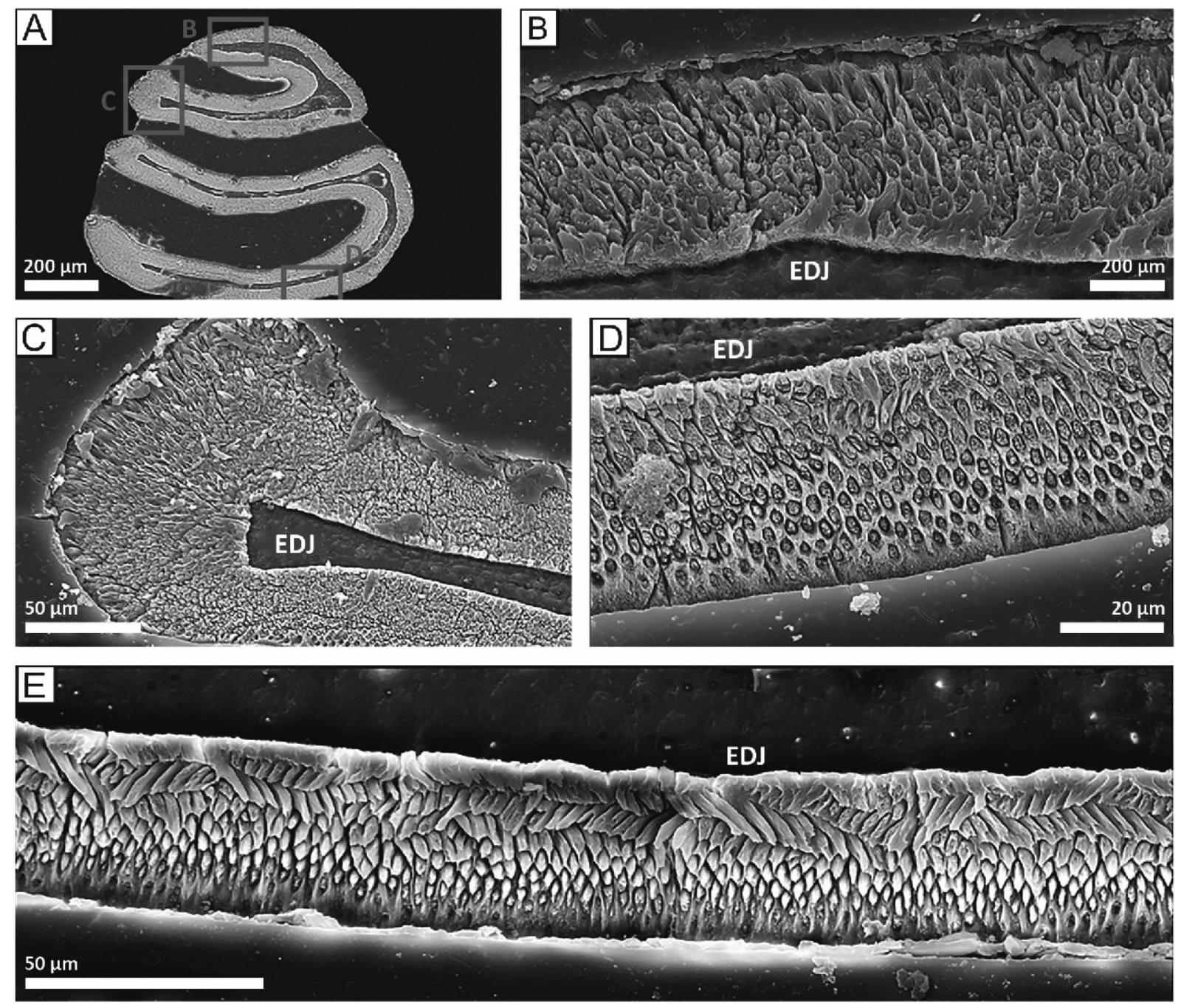

Fig. 6. Enamel structure of some Glis teeth from Węże 2 in cross section

A-D - p4: A - general view, B - anterolophid, C - protoconid, D - posterolophid; E - enamel structure of the posterolophid of $\mathrm{m} 1$ showing a BRLE (basal ring of lamellar enamel) near the base of the crown; EDJ - enamel-dentine junction

The observations performed for the purpose of this study show that the enamel structure is simple and similar along the whole tooth perimeter. It is formed predominantly of radial enamel. A thin layer of lamellar enamel, occurring close to the enamel-dentine junction (EDJ), may be present (Fig. 6). The lamellar enamel forms a structure known as the basal ring of lamellar enamel (BRLE). Such a type of schmelzmuster, where radial and lamellar enamel co-occur, was recognized as the C-type (Koenigswald, 2004). Generally, it is typical of the Myomorpha, the species-rich clade of rodents encompassing the Muroidea (the mouse-like rodents) and Gliridae (Koenigswald, 2004; see also Nowakowski et al., 2018).

\section{CONCLUSIONS}

At the Villafranchian site of Węże 2 the genus Glis is represented by over 200 isolated teeth and a partially preserved mandible. The material belongs to $G$. minor and G. sackdillingensis, two species that differ only in the dimensions of their cheek teeth. Based on the morphometric criteria elaborated by Striczky and Pazonyi (2014), the mandible, all 62 isolated M1 specimens, as well as $61 \mathrm{~m} 1$ specimens, are assigned to Glis minor, while $6 \mathrm{~m} 1$ specimens are assigned to Glis sackdillingensis. The remaining material is assigned to G. ex gr. sackdillingensis-minor, due to the lack of clear morphometric or morphological criteria permitting their attribution to one of the species with sufficient certainty. The presence of the dormouse genus Glis suggests that the fossil assemblage of Węże 2 represents at least a partly arboreal environment.

The traditional two-species paradigm for G. ex gr. minor-sackdillingensis is maintained in this study as the statistical analysis performed by Striczky and Pazonyi (2014) on the Glis material collected at several central European sites seems to support it. However, applying the criteria elaborated through that analysis to the previously described G. minor/G. sackdillingensis material also shows these two species as having almost parallel stratigraphic ranges and not infrequently coexisting at the same site, which was previously not thought to be the case. A more comprehensive statistical analysis may be needed to confirm or disprove the existence of two separate species, as opposed to one species, G. sackdillingensis, which displays some intraspecific variability of morphometric traits and a general evolutionary tendency to increase in size.

It is also possible that further studies of enamel structures are going to provide some additional means of distinguishing these species as differences in diet and lifestyle may have led to differences in enamel structure. Preliminary observations of the 
enamel of the dormice from Węże 2 show that the structure typical of the Myomorpha is discernible, formed predominantly by radial enamel, with a thin layer of lamellar enamel occurring close to the enamel-dentine junction.

Acknowledgements. I would like to thank $\measuredangle$. FostowiczFrelik (Institute of Paleobiology, Polish Academy of Sciences) for helping me during my work on this paper, particularly for her insights into enamel structure. I express my thanks to E. Hara (IPal PAS) for sorting and preparing the material, A. Zaremba (IPal PAS) for making samples for the enamel study, as well as C. Kulicki (IPal PAS) and P. Bącal (IPal PAS) for helping with SEM work. This research did not receive any specific grant from funding agencies in the public, commercial, or not-for-profit sectors.

\section{REFERENCES}

Agadzhanyan, A.K., Vislobokova, I.A., Shunkov, M.V., Ulyanov, V.A., 2017. Pleistocene mammal fauna of the Trlica locality, Montenegro. Fossil Imprint, 73: 93-114.

Aguilar, J.-P., Bachelet, B., Bonnet, A., Lesage, J.-L., Michaux, J., 1993. Le gisement karstique du Grand Serre (commune de Montclus, Gard). Données nouvelles sur les faunes de rongeurs du Pliocène terminal dans le Sud de la France. Geobios, 26 633-640.

Aguilar, J.-P., Calvet, M., Michaux, J., 1986. Description des rongeurs Pliocènes de la faune du Mont-Hélène (Pyrénées-Orientales, France), nouveau jalon entre les faunes de Perpignan (Serrat-d'en-Vacquer) et de Sète. Palaeovertebrata, 16: 127-144.

Aguilar, J.-P., Crochet, J.-Y., Hebrard, O., Le Strat, P., Michaux, J., Pedra, S., Sigé, B., 2002. Les micromammifères de Mas Rambault 2, gisement karstique du Pliocène supérieur du Sud de la France: âge, paléoclimat, géodynamique. Géologie de la France, 4: 17-37.

Amori, G., Aulagnier, S., Hutterer, R., Kryštufek, B., Yigit, N., Mitsain, G., Palomo, L.J., 2008. Eliomys munbyanus. The IUCN Red List of Threatened Species 2008 https://dx.doi.org/10.2305/IUCN.UK.2008.RLTS.T136469A429 5693.en

Bednarczyk, A., 1993. Early Pliocene terrestrial fauna with Glirulus (Mammalia) from Pańska Góra (Częstochowa Upland, Poland). Acta Zoologica Cracoviensia, 36: 233-240.

Bruijn de, H., 1998. Vertebrates from the Early Miocene lignite deposits of the opencast mine Oberdorf (Western Styrian Basin, Austria): 6. Rodentia 1 (Mammalia). Annalen des Naturhistorischen Museums in Wien, 99A: 99-137.

Bruijn de, H., van der Meulen, A.J., 1975. The Early Pleistocene Rodents from Tourkobounia-1 (Athens, Greece). Proceedings of the Koninklijke Nederlandse Akademie van Wetenschappen Series B, 78: 314-338.

Chaline, J., 1972. Les Rongeurs du Pléistocène moyen et supérieur de France: systématique, biostratigraphie, paléoclimatologie, avec un essai de stratigraphie climatique du Pléistocène européen. Editions du Centre national de la recherche scientifique.

Colombero, S., Alba, D.M., D’Amico, C., Delfino, M., Esu, E., Giuntelli, P., Harzhauser, M., Mazza, P.P.A., Mosca, M., Neubauer, T.A., Pavia, G., Pavia, M., Villa, A., Carnevale, G. 2017. Late Messinian mollusks and vertebrates from Moncucco Torinese, north-western Italy. Paleoecological and paleoclimatological implications. Palaeontologia Electronica, 20.1.10A $1-66$.

Colombero, S., Pavia, G., Carnevale, G., 2014. Messinian rodents from Moncucco Torinese, NW Italy: palaeobiodiversity and biochronology. Geodiversitas, 36: 421-475.

Čermák, S., Wagner, J., Fejfar, O., Horáček, I., 2007. New Pliocene localities with micromammals from the Czech Republic: a preliminary report. Fossil Record, 10: 60-68.

Daams, R., Bruijn de, H., 1994. A classification of the Gliridae (Rodentia) on the basis of dental morphology. Hystrix (n.s.), 6 : 3-50.
Dahlmann, T., 2001. Die Kleinsäuger der unter-pliozänen Fundstelle Wölfersheim in der Wetterau (Mammalia. Lipotyphla, Chiroptera, Rodentia). Courier Forschungsinstitut Senckenberg, 227: 1-129.

Daoud, A., 1993. Evolution of Gliridae (Rodentia, Mammalia) in the Pliocene and Quaternary of Poland. Acta Zoologica Cracoviensia, 36: 199-231.

Daxner-Höck, G., 2005. Eomyidae and Gliridae from Rudabánya. Palaeontographia Italica, 90: 149-161.

Daxner-Höck, G., Höck, E., 2009. New data on Eomyidae and Gliridae (Rodentia, Mammalia) from the Late Miocene of Austria. Annalen des Naturhistorischen Museums in Wien, $111 \mathrm{~A}$ : 375-444.

Dehm, R., 1962. Altpleistocäne Säuger von Schernfeld bei Eichstätt in Bayern. Mitteilungen der Bayerischen Staatssammlung für Paläontologie und historische Geologie, 2: 17-61.

Fostowicz-Frelik, Ł., 2007. Revision of Hypolagus (Mammalia: Lagomorpha) from the Plio-Pleistocene of Poland: qualitative and quantitative study. Annales Zoologici, 57: 541-590.

Fostowicz-Frelik, Ł., Nadachowski, A., KowalewskaGroszkowska, M., 2012. New data on the Miocene stem lagomorph Eurolagus fontannesi, and its northernmost record. Acta Palaeontologica Polonica, 57: 1-20.

Heller, F., 1930. Eine Forest-Bed-Fauna aus der Sackdillinger Höhle (Oberpfalz). Neues Jahrbuch für Mineralogie Geologie und Paläontologie B, 63: 247-298.

Hellmund, M., Ziegler, R., 2012. A Ruscinian mammalian microfauna from a fissure filling near Sondershausen (Thuringia, Central Germany). Swiss Journal of Palaeontology, 131: 77-94.

Holden, M.E., 2005. Family Gliridae. In: Mammal species of the World: A Taxonomic and Geographic Reference, 3rd Edition (eds. D.E., Wilson and D.M. Reeder): 819-841. The John Hopkins University Press.

Holden, M.E., Levine, M.S., 2009. Systematic revision of sub-Saharan African Dormice (Rodentia: Gliridae: Graphiurus). Part II: Description of a new species of Graphiurus from the Central Congo Basin, including morphological and ecological niche comparisons with G. crassicaudatus and G. lorraineus. Bulletin of the American Museum of Natural History 2009: 314-355.

Horáček, I., Bláha, V., Wagner, J., Čermák, S., Žák, K., Ryšánek, K., 2016. Speleology and Quaternary research at Chlum Hill near Srbsko: history and current achievements (in Czech with English summary). Český kras, 42: 5-22.

Hordijk, K., de Bruijn, H., 2009. The succession of rodent faunas from the Mio/Pliocene lacustrine deposits of the Florina-Ptolemais-Servia Basin (Greece). Hellenic Journal of Geosciences, 44: 21-103.

Jánossy, D., 1986. Pleistocene vertebrate faunas of Hungary. Developments in Palaeontology and Stratigraphy, 8.

Kalthoff, D.C., 2000. Die Schmelzmikrostruktur in den Incisiven der hamsterartigen Nagetiere und anderer Myomorpha (Rodentia, Mammalia). Palaeontographica A., 259: 1-193.

Koenigswald v., W., 1993. Die Schmelzmuster in den Schneidezähnen der Gliroidea (Gliridae und Seleviniidae, Rodentia, 
Mammalia) und ihre systematische Bedeutung. Zeitschrift für Säugetierkunde, 58: 92-115.

Koenigswald v., W., 2004. Enamel microstructure in rodent molars, classification, and parallelisms, with a note on the systematic affiliation of the enigmatic Eocene rodent Protoptychus. Journal of Mammalian Evolution, 11: 127-142.

Koufos, G.D., 2001. The Villafranchian mammal faunas and biochronology of Greece. Bollettino della Societè Paleontologica Italiana, 40: 217-223.

Kowalski, K., 1956. Insectivores, bats and rodents from the early Pleistocene bone breccia of Podlesice near Kroczyce (Poland). Acta Palaeontologica Polonica, 1: 331-398.

Kowalski, K., 1960a. An early Pleistocene fauna of small mammals from Kamyk (Poland). Folia Quaternaria, 1: 1-24.

Kowalski, K, 1960b. Pliocene insectivores and rodents from Rębielice Królewskie (Poland). Acta Zoologica Cracoviensia, 5 155-202.

Kowalski, K., 1963. The Pliocene and Pleistocene Gliridae (Mammalia, Rodentia) from Poland. Acta Zoologica Cracoviensia, 8: 533-567.

Kowalski, K., 1990. Stratigraphy of Neogene mammals of Poland. NATO ASI Series. Series A: Life Sciences, 180: 193-209.

Kretzoi, M., 1959. Insectivoren, Nagetiere und Lagomorphen der jüngstpliozänen Fauna von Csarnota im Villanyer Gebirge (Südungarn). Vertebrata Hugarica, 1: 237-246.

Kryštufek, B., 2010. Glis glis (Rodentia: Gliridae). Mammalian Species, 42: 195-206.

Kurtén, B., 2007. Family Gliridae, Dormice: 205-209. Pleistocene Mammals of Europe. Aldine Transaction. Routledge. https://doi.org/10.4324/9781315126470

Malez, M., Rabeder, G., 1984. Neues Fundmaterial von Kleinsäugern aus der altpleistozänen Spaltenfüllung Podumci 1 in Norddalmatien (Kroatien, Jugoslawien). Beiträge zur Paläontologie von Österreich, 11: 439-510.

Marchetti, M., Parolin, K., Sala, B., 2000. The Biharian fauna from Monte La Mesa (Verona, northeastern Italy). Acta Zoologica Cracoviensia, 43: 79-105.

Martín-Suárez, E., 1998. The Pliocene Moreda Karstic complex. In: The Plio-Pleistocene Vertebrate Succession of the Guadix-Baza Basin (SE Spain) (eds. J. Agusti, O. Oms and E. Martín-Suárez): 58-63. European Quaternary Mammal Research Association (INQUA-SEQS).

Maul, L., 2001. Die Kleinsäugerreste (Insectivora, Lagomorpha, Rodentia) aus dem Unterpleistozän von Untermassfeld. In: Kahlke, R.D., 2001. Das Pleistozän von Untermassfeld bei Meiningen (Thüringen). Teil 3 . Dr. Rudolf Habelt $\mathrm{GMBH}$ : 783-916.

Mörs, T., Koenigswald von, W., Hocht von der, F., 1998. Rodents (Mammalia) from the late Pliocene Reuver Clay of Hambach (Lower Rhine Embayment, Germany). Mededelingen Nederlands Instituut voor Toegepaste Geowetenschappen TNO, 60: 135-160.

Nadachowski, A., 1989. Gryzonie - Rodentia (in Polish). Folia Quaternaria, 59-60: 151-176.

Nadachowski, A., Pawłowski, J., Stworzewicz, E., 1989. Charakterystyka stanowisk i ich korelacja stratygraficzna (in Polish). Folia Quaternaria, 59-60: 5-19.
Nadachowski, A., Stefaniak, K., Szynkiewicz, A., Marciszak, A., Socha, P, Schick, P., August C., 2011. Biostratigraphic importance of the Early Pleistocene fauna from Żabia Cave (Poland) in Central Europe. Quaternary International, 243: 204-218.

Nowakowski, D., Rekovets, L., Kovalchuk, O., Pawlina, E., Demeshkant, V., 2018. Enamel ultrastructure of molars in †Anomalomys gaillardi and some spalacid taxa (Rodentia, Mammalia). Palaeontologia Electronica, 21.2.18A: 1-15.

Paunovic, M., Rabeder, G., 1996. Die altpleistozänen Kleinsäugerfaunen Razvodje und Tatinja draga in Süd-Kroatien. Beiträge zur Paläontologie, 21: 69-84.

Pazonyi, P., Mészáros, L., Hír, J., Szentesi, Z., 2016. The lowermost Pleistocene rodent and soricid (Mammalia) fauna from Beremend 14 locality (South Hungary) and its biostratigraphical and palaeoecological implications. Fragmenta Paleontologica Hungarica 33: 99-134.

Popov, V.V., 2004. Pliocene small mammals (Mammalia, Lipotyphla, Chiroptera, Lagomorpha, Rodentia) from Muselievo (North Bulgaria). Geodiversitas, 26: 403-491.

Rose, K.D., 2006. The Beginning of the Age of Mammals. The Johns Hopkins University Press.

Rzebik-Kowalska, B., 1989. Owadożerne - Insectivora (in Polish). Folia Quaternaria, 59-60: 109-127.

Siori, M.S., Boero, A., Carnevale, G., Colombero, S., Delfino, M., Sardella, R., Pavia, M., 2014. New data on Early Pleistocene vertebrates from Monte Argentario (Central Italy). Paleoecological and biochronological implications. Geobios, 47: 403-418.

Stefaniak, K., 1995. Late Pliocene cervids from Węże 2 in southern Poland. Acta Palaeontologica Polonica, 40: 327-340.

Stefaniak, K., Nadachowski, A., Marciszak, A., Szynkiewicz, A., Socha, P., 2009. Early Pleistocene fauna and sediments of the Żabia Cave. Studies of the Faculty of Earth Sciences, University of Silesia, 56: 173-189.

Stefaniak, K., Ratajczak, U., Kotowski, A., Kozłowska, M., Mackiewicz, P., 2020. Polish Pliocene and Quaternary deer and their biochronological implications. Quaternary International, 546: 64-83.

Striczky, L., Pazonyi, P., 2014. Taxonomic study of the dormice (Gliridae, Mammalia) fauna from the late Early Pleistocene Somssich Hill 2 locality (Villány Hills, South Hungary) and its palaeoecological implications. Fragmenta Palaeontologica Hungarica, 31: 51-81.

Sulimski, A., 1962. On a new finding of fossil vertebrate fauna near Działoszyn (in Polish with English summary). Przegląd Geologiczny, 10: 219-223.

Sulimski, A., 1964. Pliocene Lagomorpha and Rodentia from Węże 1 (Poland). Acta Palaeontologica Polonica, 9: 149-244.

Sulimski, A., Szynkiewicz, A., Wołoszyn, B., 1979. The Middle Pliocene micromammals from Central Poland. Acta Palaeontologica Polonica, 24: 377-403.

Terzea, E., 1996. Biochronology of the Pleistocene deposits at Betfia (Bihor, Romania). Acta Zoologica Cracoviensia, 39: 531-540.

Urban, J., Hercman, H., Ochman, K., Kasza, A., 2019. Record of the Pleistocene at karst sites of the Świętokrzyskie (Holy Cross) Mountains region - a review. Studia Quaternaria, 36: 87-108. 